\title{
Analisis Strategi Bersaing dan Strategi Bertahan pada Industri Mikro dan Kecil Panganan Keripik Kemasan di Kecamatan Coblong Kota Bandung Jawa Barat Tahun 2020 Ditengah Situasi Sulit Penyebaran Pandemi COVID-19
}

\author{
Arief Yanto Rukmana ${ }^{1}$, Tuntun Ariadi Sukanta ${ }^{2}$ \\ Program Studi Manajemen ${ }^{1,2}$ \\ Sekolah Tinggi Ilmu Ekonomi STAN IM, J1. Jakarta No.79 Bandung ${ }^{1,2}$ \\ Email : ariefyantorukmana@gmail.com ${ }^{1}$, ariadi7980@gmail.com ${ }^{2}$
}

\begin{abstract}
ABSTRAK
Penelitian ini bertujuan untuk mengetahui dan menganalisis strategi bersaing dan strategi bertahan pada usaha mikro dan kecil panganan keripik kemasan di kecamatan coblong, Kota Bandung tahun 2020. Data yang digunakan merupakan data primer dan sekunder. Data primer diperoleh dari hasil survei lapangan dan wawancara, sedangkan data sekunder dari lembaga atau instansi terkait seperti Dinas Perindustrian dan Perdagangan, Badan Pusat Statistik serta Paguyuban ABDSI Korwil Jabar yang berada di sentra industri Panganan Keripik Kemasan. Alat analisis yang digunakan untuk strategi bersaing adalah dengan Teori Lima Kekuatan Persaingan dari Porter (1980). Sedangkan untuk analisis deskriptif digunakan untuk menganalisis strategi bertahan pada usaha mikro dan kecil produsen Panganan Keripik Kemasan. Berdasarkan pendekatan metode Lima Kekuatan Persaingan dari Porter (1980), produsen keripik mampu bersaing dengan harga, pengembangan produk, promosi, dan distribusi produk. Strategi Bertahan produsen Panganan Keripik Kemasan adalah dengan adanya model dari porter dari strategi bersaing, produsen mampu bertahan dari persaingan antar produsen keripik yang lebih besar karena strategi bertahan yang digunakan oleh produsen yaitu harga yang terjangkau bagi para konsumen.
\end{abstract}

Kata kunci : strategi bersaing, strategi bertahan, industri keripik

\section{ABSTRACT}

This study aims to determine and analyze the competitive and survival strategies in micro and small scale packaging chips packaging in Coblong sub-district, Bandung City in 2020. The data used are primary and secondary data. Primary data were obtained from the results of field surveys and interviews, while secondary data from institutions or related institutions such as the Department of Industry and Trade, the Central Statistics Agency and the ABDSI Association of West Java Regional Corporations located in the center of the Packaging Chips Handling Industry. The analytical tool used for the competitive strategy is the Theory of Five Competition Competitions from Porter (1980). As for the descriptive analysis, it is used to analyze the survival strategy of micro and small businesses in the packaging of chips packaging. Based on Porter's (1980) method of Five Competition Power methods, chips producers are able to compete with price, product development, promotion, and product distribution. The survival strategy of producers of packaged chips is that with the porter's model of a competitive strategy, producers are able to survive the competition between larger chip producers because of the survival strategy used by producers that is affordable prices for consumers. 
Keywords: competitive strategy, survival strategy, chips industry

\section{PENDAHULUAN}

\subsection{Latar Belakang}

Urgensi Eksistensi Usaha Mikro dan Kecil (UMK) merupakan salah satu bagian penting dalam sebuah perekonomian suatu daerah maupun negara. Selain memiliki peranan penting dalam laju pertumbuhan yang menentukan perekonomian masyarakat, UMK juga membantu pemerintah dalam menciptakan lapangan Pekerjaan baru. UMK terbukti mampu bertahan pada kondisi krisis. Hal ini mendasari pendapat bahwa UMK menjadi pilihan untuk dikembangkan pada kondisi ekonomi yang kurang baik. UMK menjadi sektor yang mampu bertahan dibandingkan dengan sektor-sektor lain yang memiliki skala lebih besar.

Perkembangan UMK memberikan kontribusi signifikan pada pengembangan perekonomian daerah dan dalam pemberdayaan masyarakat. Perkembangan dari sisi jumlah maupun penyerapan tenaga kerja terlihat pada Gambar berikut.

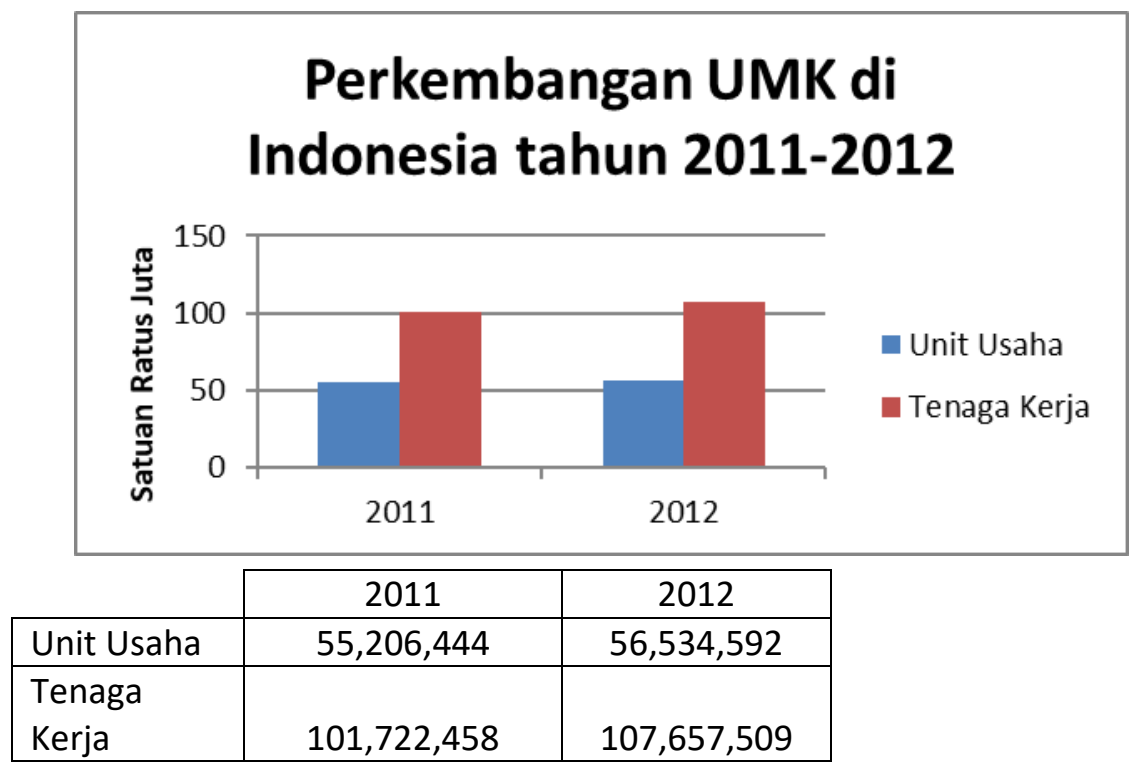

Gambar 1: Perkembangan UMK di Indonesia tahun 2011-2012 Sumber : BPS (2011-2012).

Gambar 1 menunjukkan jumlah perkembangan UMK di Indonesia tahun 2011 terdapat 55.206.444 unit usaha, jumlah ini meningkat di tahun 2012 sebanyak 56.534.592. Sedangkan dari sisi penyerapan tenaga kerja, UMK mampu menyerap 
101.722.458 orang dan jumlahnya meningkat di tahun 2012 menjadi 107.657.509 orang. Kemampuannya dalam penyerapan tenaga kerja maka UMK perlu untuk terus dikembangkan. Hal ini akan membantu pemerintah dalam penyerapan tenaga kerja dan mengurangi pengangguran. Meski demikian masih terdapat banyak permasalahan dalam UMK di Indonesia, yaitu salah satunya kurang permodalan, kesulitan dalam pemasaran, struktur organisasi sederhana dengan pembagian kerja yang tidak baku, kualitas manajemen rendah, SDM terbatas dan kualitasnya rendah, kebanyakan tidak mempunyai laporan keuangan, aspek legalitas lemah, dan rendahnya kualitas teknologi. Permasalahan ini mengakibatkan lemahnya jaringan usaha, keterbatasan kemampuan penetrasi pasar dan diversifikasi pasar, skala ekonomi terlalu kecil sehingga sukar menekan biaya, margin keuntungan sangat kecil, dan lebih jauh lagi UKM tidak memiliki keunggulan kompetitif (Arief Rahmana, et al. 2012:15). Salah satu jenis usaha UMK di kota Bandung adalah Keripik Ubi Cilembu (Ubinesia) dan Keripik Pisang Banana Harajuku www.bananaharajuku.com masih dalam satu holding bisnis ARF Production. Keripik Ubinesia adalah makanan khas Bandung yang terbuat dari campuran ubi ungu cilembu dengan paduan gula, yang dibungkus dengan tepung beras tipis, lalu digoreng. Industri Keripik ini sangat mempengaruhi perekonomian masyarakat sekitar, terutama bagi masyarakat Kota Bandung yang sering dinamai sebagai kota industri panganan keripik karena memang terdapat banyak industri Keripik di kawasan ini. Fenomena ini memberi dampak kesenjangan antara industri besar dan industri kecil Keripik dalam kaitannya terhadap persaingan pasar. Banyak industri kecil yang sudah tidak dapat menyaingi industri besar yang kini semakin banyak. Hal itu didasari oleh permasalahan internal yang mencakup kurangnya modal untuk produksi maupun distribusi, keterbatasan sumber daya manusia, keterbatasan teknologi yang digunakan, serta manajemen usaha yang tidak mendukung perubahan lingkungan bisnis di dalam industri keripik. Oleh karena itu dibutuhkan kemampuan bertahan dalam industri keripik. Disamping itu, hal yang berperan penting lainnya adalah kemampuan bersaing, dimana suatu perusahaan harus mampu mengungguli para pesaingnya. Untuk dapat mencapai semua itu, suatu perusahaan juga harus memahami strategi bersaing mereka. Strategi bersaing ditentukan oleh lima faktor penentu yang berperan penting dalam merangkum 
kondisi stuktur pasar suatu industri. Menurut Porter (1980), kelima faktor tersebut antara lain: persaingan di antara perusahaan yang ada, ancaman produk atau jasa substitusi, daya tawar menawar pembeli, daya tawar menawar pemasok dan ancaman pendatang baru. Suatu perusahaan harus memperhatikan kelima faktor tersebut dalam menciptakan strategi bersaing dalam persaingan pasar yang ada.

Fokus penelitian ini adalah strategi bersaing dan strategi bertahan pada industri mikro-kecil keripik. Sedangkan fokus penelitian ini terletak di Jl. Sukasari Kecamatan Coblong, kota Kota Bandung.

\subsection{Rumusan Masalah}

Berdasarkan latar belakang yang telah dijelaskan diatas maka rumusan masalah dalam penelitian ini adalah sebagai berikut:

1. Bagaimanakah strategi bersaing pada industri mikro dan kecil panganan keripik kemasan di kecamatan Coblong Kota Bandung Tahun 2020?

2. Bagaimanakah strategi bertahan pada industri mikro dan kecil panganan keripik kemasan di kecamatan Coblong Kota Bandung Tahun 2020?

3. Bagaimanakah persaingan industri panganan keripik kemasan di kecamatan Coblong Kota Bandung Tahun 2020 dengan menggunakan model lima kekuatan Persaingan dari Porter (1980)?

\subsection{Tujuan Penelitian}

Berdasarkan rumusan masalah yang telah dikemukakan, maka penelitian ini bertujuan:

1. Untuk mengetahui dan menganalisis strategi bersaing pada industri mikro dan kecil panganan keripik kemasan di kecamatan Coblong Kota Bandung Tahun 2020.

2. Untuk mengetahui dan menganalisis strategi bertahan pada industri mikro dan kecil panganan keripik kemasan di kecamatan Coblong Kota Bandung Tahun 2020.

3. Untuk mengetahui dan menganalisis persaingan industri panganan keripik kemasan di kecamatan Coblong Kota Bandung Tahun 2020 dengan 
menggunakan model lima kekuatan Persaingan dari Porter (1980).

\section{METODE PENELITIAN}

\subsection{Lokasi Penelitian}

Lokasi penelitian yang dipilih merupakan sentra industri panganan keripik kemasan Kecamatan Coblong, Kota Bandung, Jawa Barat.

\subsection{Data dan Sumber Data}

Data yang digunakan dalam penelitian ini merupakan data primer dan data sekunder. Data primer diperoleh dengan melakukan survei dan wawancara. Wawancara dilakukan kepada produsen panganan keripik kemasan Kecamatan Coblong Kota Bandung. Data sekunder yang diperoleh dari lembaga atau instansi terkait seperti Dinas Perindustrian dan Perdagangan, Badan Pusat Statistik serta Paguyuban ABDSI Koorwil Jabar yang berada di sentra industri keripik Kota Bandung Jawabarat.

\subsection{Metode Pengumpulan data}

Metode pengumpulan data dalam penelitian ini adalah dengan survei lapangan dan wawancara. Survei lapangan dilakukan untuk mendapatkan data primer dalam survei ini responden diminta untuk mengisi beberapa pertanyaan yang telah disiapkan. Setelah itu dilakukan wawancara mendalam kepada setiap responden untuk memperoleh informasi yang belum tercantum dalam daftar pertanyaan (kuesioner). Hasil dari wawancara yang diambil jumlah populasi adalah sebanyak 60 responden, dikarenakan populasi industri kecil (produsen keripik) yang berlokasi di Wilayah Kota bandung, Kecamatan Coblong berdasarkan survei keseluruhan berjumlah 60 unit usaha. Responden diambil dari produsen keripik di Wilayah Kecamatan Coblong. Kota Bandung

\subsection{Alat Analisis}

\subsubsection{Analisis Deskriptif}

Hasil dari wawancara terhadap responden produsen keripik akan menjadi landasan untuk menganalisis pertanyaan-pertanyaan dari perumusan masalah yang sudah 
ada. Analisis deskriptif ini membantu untuk menjelaskan bagaimana aspek-aspek permasalahan yang belum dapat dikuantitatifkan.

\subsubsection{Analisis Industri}

Pada analisis lima kekuatan persaingan dari Porter (1980) yang terutama dilakukan adalah menentukan siapa saja yang berperan dalam industri keripik kemudian akan dilakukan pemaparan variabel-variabel dan indikator-indikator dari kelima kekuatan persaingan dari Porter.

\subsection{Batasan Operasional}

1) Produsen keripik kemasan di kecamatan Coblong, kota Bandung, Jawa Barat berjumlah 60 produsen.

2) UMK didefinisikan sebagai unit usaha yang melakukan kegiatan produksi dan memperkerjakan tenaga kerja berkisar antara 5-19 orang. (BPS, 2013)

3) Strategi Bertahan didefinisikan sebagai kemampuan unit usaha untuk tetap dapat melaksanakan aktivitas produksi dan memperoleh penghasilan atau pendapatan dari kegiatan tersebut. (Sri Susilo dan Ariani, 2003:121)

4) Strategi Bersaing didefinisikan sebagai upaya mencari posisi bersaing yang menguntungkan dalam suatu industri, arena fundamental persaingan berlangsung. (Porter,1980)

\section{HASIL DAN PEMBAHASAN}

\subsection{Profil Responden}

Berdasarkan hasil survei pada gambar 2 menunjukkan bahwa Tenaga kerja produsen keripik terdiri dari jumlah pegawai, pegawai keluarga, dan pegawai dibayar. Untuk jumlah pegawai produsen keripik dari 1 sampai 3 orang sebesar 77 persen, 4 sampai 6 orang sebesar 20 persen, dan 7 sampai 8 orang sebesar 3 persen. Pegawai keluarga ternyata hanya 1 sampai 3 orang (100\%) yang digunakan. Sedangkan pegawai dibayar produsen keripik dari 1 sampai 3 orang sebesar 79 persen, 4 sampai 6 orang sebesar 19 persen, dan 7 sampai 8 orang sebesar 4 persen. 


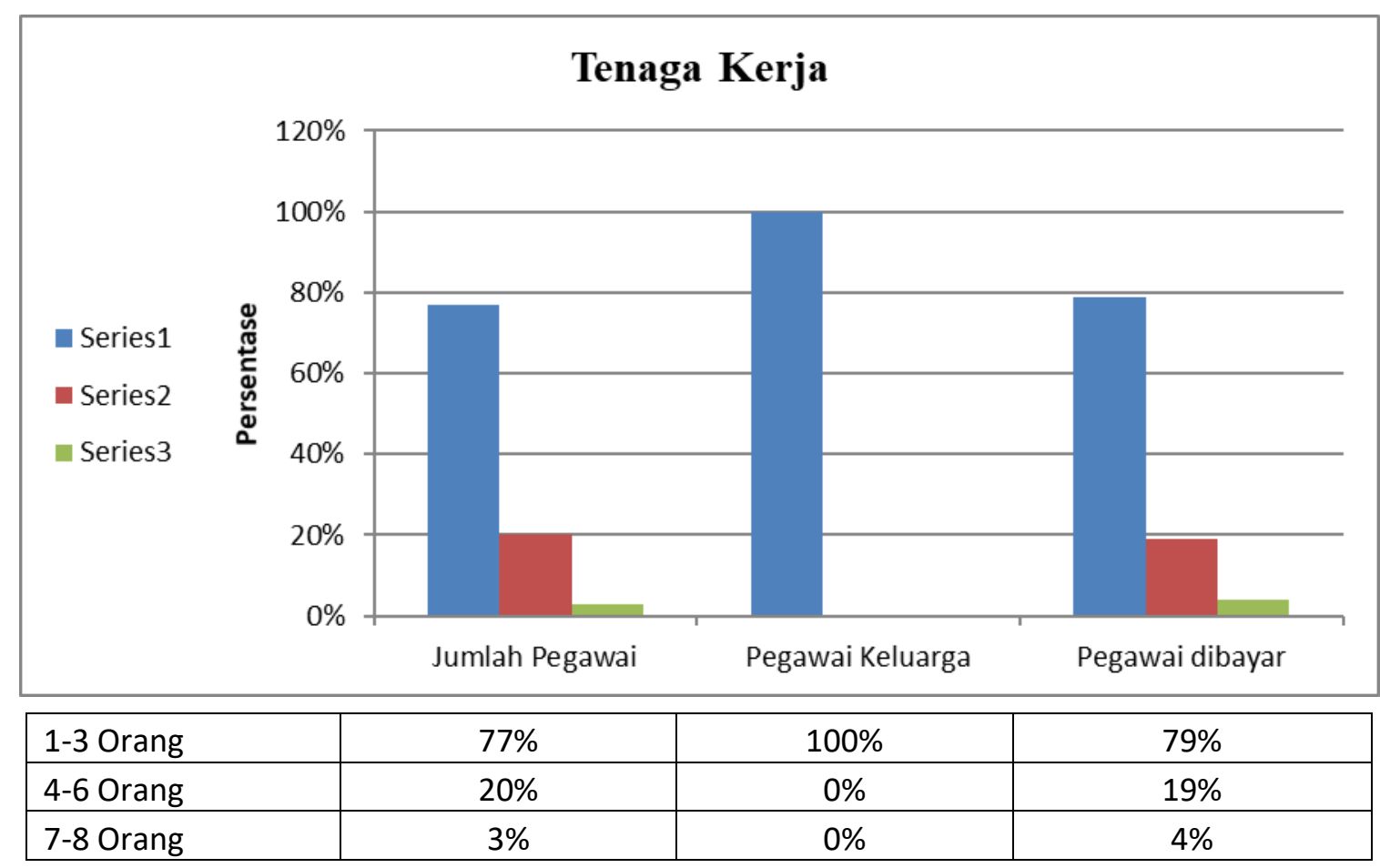

Sumber : Hasil survei April 2020 (diolah).

Gambar 2: Tenaga Kerja Produsen Keripik

Selain itu, modal yang dibutuhkan dalam membangun usaha keripik ini sebesar 5 juta rupiah. Gambar 3 menunjukkan besar modal awal produsen keripik terdapat sebanyak 29 orang responden (48\%) modal awal mereka antara dari Rp1.000.000,00 sampai Rp5.000.000,00. Modal awal kurang dari Rp1.000.000,00 sebanyak 22 orang responden (37\%), antara Rp5.000.000,00 sampai Rp10.000.000,00 sebanyak 7 orang responden (12\%) dan sisanya lebih dari Rp10.000.000,00 sebanyak 2 orang responden (3\%).

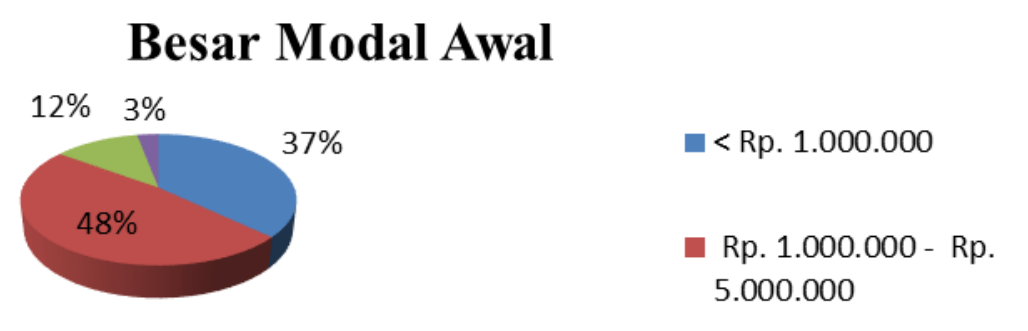

Sumber : Hasil survei April 2020 (diolah).

Gambar 3: Besar Modal Usaha Produsen Keripik 
Dalam membuka usaha keripik ini para produsen harus mempunyai produk yang menarik dari sisi jumlah, rasa, agar konsumen tertarik dan ingin membeli produk mereka. Berdasarkan dari hasil wawancara dengan salah satu responden dari perkumpulan keripik yang berada di Kemasan bernama Perkumpulan Pengusaha Panganan Kemasan tergabung dalam Perkumpulan ABDSI Koorwil Jabar ini memiliki anggota sebesar 60 orang yang dipimpin oleh Ibu Meta Mafthuhah. Perkumpulan ini diadakan setiap bulannya di tanggal 15, dalam perkumpulan tersebut menjelaskan bahwa perkumpulan mereka membuat produk keripik mulai dari rasa, isi, harga yang disepakati bersama namun masih banyak anggota yang tidak sama dalam produk keripik tersebut. Terutama dalam hal varian rasa keripik dan harga, untuk varian rasa yang disepakati menjual 4 rasa yaitu rasa green tea, coklat, keju, dan lada hitam, tetapi ada sebagian anggota menambahkan variasi rasa dalam keripik mereka menjadi 6 rasa yaitu rasa green tea, coklat, keju, lada hitam, strawberry, durian atau blueberry. Harga yang seharusnya disepakati per kotak keripik (100 Gram) adalah Rp15.000,00 tetapi ada anggota yang menjual Rp17.000,00 per kotaknya.

Dari hasil penelitian jumlah kotak keripik yang terjual per hari, sebanyak 11 responden $(18,30 \%)$ dapat menjual keripik kurang dari 10 kotak keripik, sebanyak 23 responden $(38,30 \%)$ dapat menjual keripik antara 10 sampai 30 kotak per hari, sebanyak 8 responden $(13,30 \%)$ dapat menjual keripik antara 31 samapai 50 kotak per hari, 7 responden $(11,70 \%)$ dapat menjual keripik antara 51 sampai 100 kotak keripik per hari, dan 7 responden (11,70\%) dapat menjual 100 sampai 250 kotak keripik per hari, sisanya 4 responden $(6,70 \%)$ paling banyak menjual keripik antara 251 sampai 500 kotak keripik per hari. Jika UMR per bulan untuk Daerah Istimewa Jawa Barat sebesar Rp1.108.249,00 dibulatkan menjadi Rp1.200.000,00. Asumsi gaji pegawai sebesar Rp700.000,00.

Apabila dalam suatu industri keripik membutuhkan dua pegawai, maka besar keuntungan penjualan minimal yang harus dicapai setiap industri tersebut adalah Rp1.200.000,00+2(Rp700.000,00) $=$ Rp2.600.000,00. Dengan demikian keuntungan yang harus diraih dalam sehari adalah Rp87.000,00. Asumsi apabila marjin keuntungan sebesar 20\% dan harga per kotak keripik Rp15.000,00 maka keuntungan yang diperoleh dalam satu kotak keripik adalah Rp3.000,00. Dengan 
demikian banyak kotak yang harus dijual setiap hari adalah Rp3.000,00x(jumlah kotak) $=$ Rp87.000,00. Maka jumlah minimal kotak yang harus dijual setiap hari adalah 29 kotak/hari. Sedangkan menurut hasil survei pada gambar 4, sebanyak $56,6 \%$ masih berada dibawah standar minimal jumlah penjualan setiap hari.

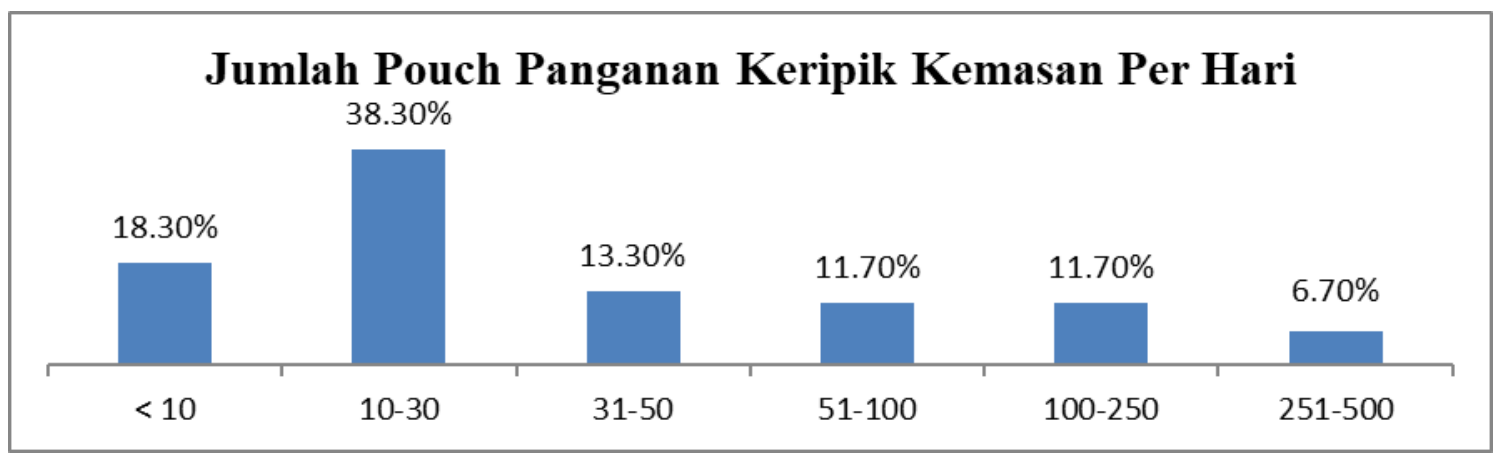

Sumber : Hasil survei April 2020 (diolah).

Gambar 4: Jumlah kotak keripik yang terjual per hari

\subsection{Strategi Bersaing}

Berdasarkan hasil survei, bahwa strategi bersaing yang dilakukan oleh para produsen keripik untuk mengenalkan produk mereka yaitu dengan cara melakukan promosi lewat tetangga, internet, serta ada yang membagikan keripik gratis orangorang yang ada dijalan, sehingga masyarakat mengerti jika produk mereka tidak kalah jauh dengan produk yang sudah terkenal. Dari hasil penelitian ini tidak sejalan dengan penelitian yang dilakukan oleh Sri Susilo (2007:27), bahwa 90\% responden keripik yang berada di kemasan tidak melakukan promosi, baik melalui media cetak atau elektronik. Dalam menjual produk, orientasi utama mereka yaitu para wisatawan luar negeri maupun dalam negeri. Selain itu, ada juga yang memasarkan produknya dengan menitipkan produk mereka ke toko-toko keripik, promosi di pasar, terminal serta di depan gang toko mereka. Hasil penelitian ini hampir sejalan dengan riset yang dilakukan Sri Susilo (2007) bahwa dalam pemasaran yang dilakukan produsen keripik terdapat empat cara yaitu (1) outlet/warung/toko yang dikelola sendiri, (2) outlet/warung/toko makanan atau pusat oleholeh yang berlokasi di dalam kota maupun di luar kota, (3) supermarket di dalam dan di luar kota, (4) pemandu wisata, tukang becak, dan pihak lainnya. Dalam menentukan harga jual dagangan para produsen adalah mereka sendiri. 
Berdasarkan survei data yang diperoleh pada gambar 4.6 mengenai persaingan usaha lainya terhadap produk barang yang sama, 41 responden atau sebesar 68,3\% adalah produsen keripik yang tetap mempertahankan kualitas produk, karena jika kualitas produk keripik dikurangi maka para konsumen tidak akan membeli lagi produknya, serta kepercayaan terhadap produk yang dibuat produsen keripik ini akan berkurang. Oleh karena itu, para produsen keripik ini tetap mempertahankan kualitas produknya agar mampu bersaing dengan usaha lain, sekaligus menjadi strategi bertahan dalam usaha mereka. Adanya kualitas dan pelayanan yang baik tentunya akan membuat para konsumen betah dan ingin membeli lagi produk mereka. Para produsen keripik tidak hanya mempertahankan kualitas produk saja tetapi mereka melakukan inovasi-inovasi baru terhadap keripik mereka agar menaikkan kualitas produk mereka lebih baik lagi. Inovasi-inovasi yang mereka buat tentang rasa keripik yang tidak dimiliki oleh usaha lain dan membuat barang mereka sedikit berbeda. Selain itu $28,3 \%$ atau 17 responden produsen keripik memilih harga. Menurut mereka apabila mereka memberikan harga yang jauh lebih murah dibandingkan dengan usaha lainnya maka akan banyak konsumen yang tertarik untuk datang dan membeli produk mereka. Sedangkan pilihan membuat barang yang sedikit berbeda dan pelayanan masing-masing memperoleh sebanyak 1 responden atau $2 \%$ yang memilih pilihan tersebut untuk bersaing dengan usaha kecil lainnya.

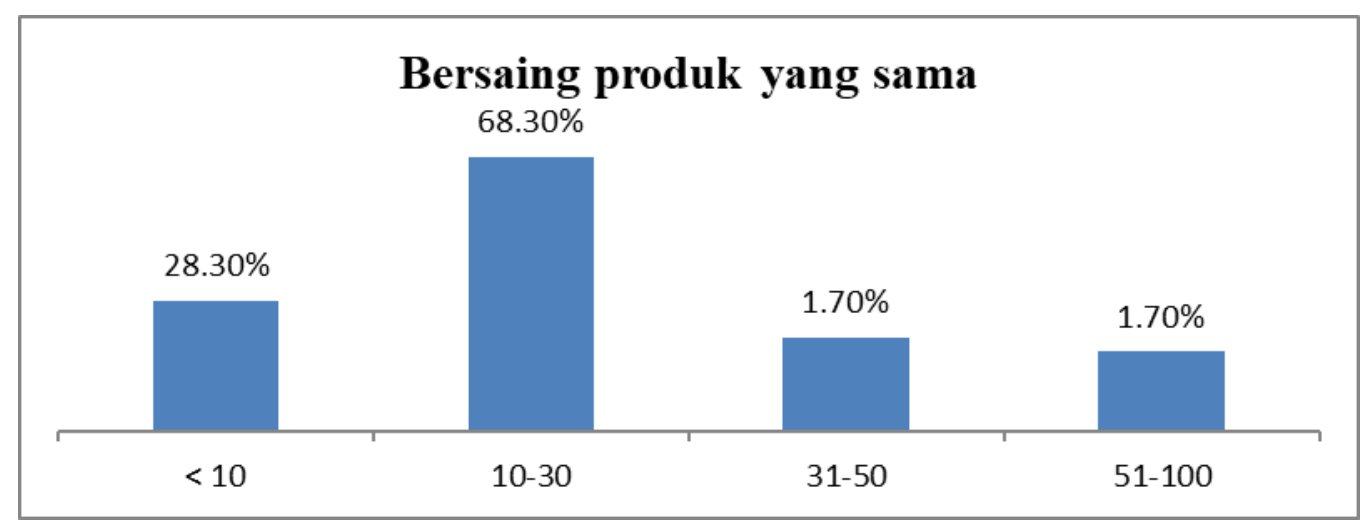

Sumber : Hasil survei April 2020 (diolah).

Gambar 5: Bersaing Dengan Usaha Kecil Lainnya Dalam Produksi Barang Yang Sama

Berdasarkan hasil survei yang diperoleh, 60 responden produsen keripik atau seluruh responden menyatakan bahwa mereka memiliki pelanggan tetap. Dari hasil 
yang didapat sebesar 50\% atau 30 responden produsen keripik menyatakan bahwa mereka memiliki harga yang terjangkau sehingga banyak pelanggan tetap yang selalu membeli di toko mereka, 38,3\% atau 23 responden produsen keripik menyatakan bahwa para produsen mengenal baik dengan pelanggan mereka dan sisanya sebesar $10 \%$ atau 6 responden produsen keripik menyatakan bahwa pelanggan tetap mereka karena adanya barang dagangan yang lebih relatif yang dimiliki oleh produsen sehingga konsumen tertarik dan menjadi pelanggan tetap mereka. Hasil ini dapat dilihat pada tabel 1 sebagai berikut

Tabel 1. Pelanggan Tetap Yang Sering Membeli

\begin{tabular}{|l|l|c|}
\hline No. & \multicolumn{1}{|c|}{ Pelanggan Yang Sering Membeli } & Jumlah (\%) \\
\hline 1 & $\begin{array}{l}\text { Pelanggan tetap tersebut kenal baik dengan } \\
\text { anda }\end{array}$ & $23(38 \%)$ \\
\hline 2 & Barang dagangan yang anda jual lebih variatif & $6(10 \%)$ \\
\hline 3 & Harga barang dagangan anda lebih terjangkau & $30(50 \%)$ \\
\hline 4 & Lainnya & $1(2 \%)$ \\
\hline
\end{tabular}

Sumber : hasil survey April 2020 (diolah)

\subsection{Strategi Bertahan}

Dalam penelitian strategi bertahan seperti yang dilakukan oleh Sri Susilo (2009) menyatakan bahwa strategi bertahan dapat dikategorikan oleh responden menjadi dua yaitu: (1) Menaikkan harga jual produk, dam (2) tidak menaikkan harga produk. Berdasarkan hasil survei dari strategi bertahan dalam kenaikkan bahan baku menunjukkan bahwa ketika terjadi kenaikan harga bahan baku keripik, 53 responden $(88,3 \%)$ akan menaikkan harga jual keripik ketika terjadi kenaikan harga bahan baku produksi keripik. Para produsen tidak bersedia mengurangi kualitas produksi yang telah mereka ciptakan sebab mereka tidak ingin mengecewakan para konsumen. Sedangkan 6 reponden $(10,0 \%)$ memilih harga keripik tidak naik. Menurut mereka apabila menaikkan harga barang para konsumen akan cenderung tidak mau untuk membeli produk mereka. Selain itu, memilih untuk mengurangi marjin keuntungan mereka. Sisanya 1 responden $(1,7 \%)$ menyatakan bahwa apabila harga bahan baku naik maka produsen ini, akan menurunkan kualitas produk keripik dari segi ukuran dan rasa serta harga jual yang digunakan tetap. Apabila mereka tidak menurunkan kualitas pada saat harga naik, mereka akan mengalami kerugian. Oleh karena itu, produsen ini tetap mengambil resiko agar tetap bertahan dari persaingan. Strategi bertahan yang lain adalah dengan menerapkan harga yang 
tetap atau tidak berubah dan atau diterapkan dengan strategi bertahan yang lain. Hasil ini dapat dilihat pada gambar 6 berikut.

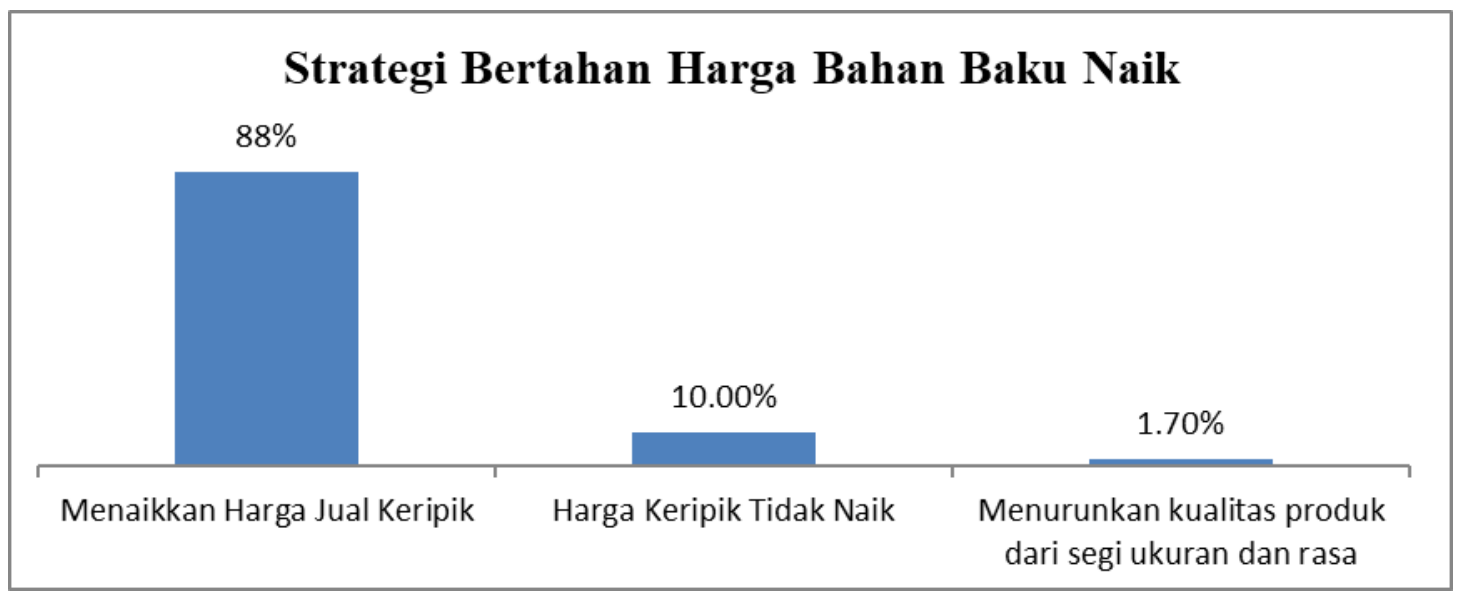

Sumber : Hasil survei April 2020 (diolah).

Gambar 6: Strategi Bertahan Harga Bahan Baku Naik

Hasil penelitian ini berdasarkan para produsen yang diwawancara mereka memilih untuk menaikkan harga, karena apabila tidak menaikkan harga mereka rugi namun disisi lain para produsen harus mengambil resiko untuk mengurangi kualitas dari segi ukuran produk yang dijual tetapi rasa tetap sama.

\subsection{Lima Kekuatan Persaingan dari Porter}

1) Persaingan Antara Perusahaan Persaing para produsen keripik industri kecil ini adalah beberapa produsen keripik yang besar. Sebab produsen keripik industri besar memiliki lokasi yang strategis dibandingkan produsen industri kecil. Ketika terjadi kenaikkan harga BBM/elpiji dan bahan baku, produsen keripik industri kecil mampu bersaing dengan produsen besar lainnya. Produsen keripik lainnya mengurangi kualitas agar dapat memperoleh keuntungan, sehingga produsen keripik yang mengurangi kualitas kurang diminati para konsumen. Banyak produsen rugi saat terjadi kenaikkan harga terjadi, oleh karena itu sebagian para produsen tutup sementara. Meskipun terjadi kenaikkan harga BBM/elpiji dan bahan baku, produsen industri kecil ini tetap mempertahankan kualitas walaupun harus mengurangi keuntungan. Kualitas produk, harga, dan varian rasa membuat konsumen akan tetap loyal membeli produk yang dijual mereka. Selain itu, strategi yang dilakukan adalah peningkatan alat-alat produksi agar dalam memproduksi keripik semakin baik 
dan efisien sehingga dapat membantu kegiatan perekonomian semakin baik lagi. Adapun, produsen industri kecil sebagian besar memberikan diskon kepada konsumen dengan pembelian produk yang ditentukan.

2) Ancaman dari pesaing potensial (potential entrants) Dalam menghadapi pendatang baru diperlukan strategi yang terutama adalah merek dagang, struktur modal, diferensiasi produk dan skala ekonomis. Modal yang diperlukan dalam membangun usaha mikro kecil keripik ini adalah antara Rp1.000.000,00 sampai Rp5.000.000,00. Dalam modal tersebut sudah termasuk biaya total yaitu produksi seperti bahan baku, alat, dan Tenaga Kerja, serta perijinan untuk membuka usaha. Industri kecil keripik ini berfokus pada kualitas keripik. Selain itu, produsen keripik ini memiliki keunggulan dalam harga. Harga yang murah dapat menarik konsumen untuk membeli produk yang dijual. Semakin banyak permintaan dan produksi, maka akan meningkatkan keuntungan serta dapat menopang perekonomian industri kecil produsen keripik. Selain harga, adapun inovasi terhadap varian rasa keripik. Varian rasa yang dimiliki para produsen, menjadi produk unggulan keripik yang dapat menarik pangsa pasar. Varian rasa yang unik yang tidak dimiliki oleh produsen lain menjadi nilai tambah bagi produsen keripik industri kecil dalam memasarkan produk mereka. Ditambah dengan adanya sertifikasi dari Balai Pengawasan Obat Makanan dapat mencegah produsen lain untuk menjual makanan yang tidak layak dijual, sehingga para produsen keripik usaha mikro kecil tidak perlu takut terhadap pendatang baru yang masuk. Oleh karena itu, harga, kualitas, varian rasa serta sertifikasi yang dimiliki produsen keripik usaha mikro kecil inilah yang menjadi salah satu ancaman bagi para pendatang baru untuk masuk ke pangsa pasar.

3) Ancaman dari produk pengganti (substitute products) Dalam ancaman produk pengganti dari keripik, sampai saat ini belum terdeteksi atau belum ada produk yang mampu mengganti. Maka dari itu, para produsen keripik harus melakukan inovasi-inovasi agar dapat mengantisipasi ancaman produk pengganti.

4) Daya Tawar Pembeli (buyer's power) Dalam jumlah permintaan yang diperoleh produsen industri kecil ini cukup besar dengan daya beli konsumen. Selain itu, strategi yang dijalankan oleh para produsen keripik dalam memasarkan produk 
mereka adalah dengan menitipkan produk mereka ke toko oleh-oleh terdekat, mengunjungi serta mendatangi wisatawan yang datang ke kota Jawa Barat. Kemudian memberikan promosi kepada konsumen yang belum mengetahui produk mereka dengan membagikan keripik gratis ke semua orang. Lalu setiap bulan september tanggal 15 para produsen keripik mengadakan festival keripik. Sehingga masyarakat dapat merasakan dan mencicipi keripik buatan industri kecil, bahwa buatan keripik industri kecil tidak kalah dengan buatan produsen lainnya.

5) Daya Tawar Pemasok (supplier's power) Dalam industri kecil keripik ini bahan baku yang digunakan dalam memproduksi keripik adalah tepung terigu, green tea, keju, coklat, lada hitam, perasa atau essens (durian, strawberry, blueberry), mentega, gula, minyak, dan garam mudah didapatkan. Bahan-bahan inilah yang akan digunakan dalam memproduksi keripik dengan berbagai varian rasa. Berdasarkan survei $98 \%$ bahan baku yang diperoleh berasal dri dalam kota sehingga dapat diperoleh dengan mudah bahan baku yang dibutuhkan dalam pembuatan produksi keripik. Bahan baku dapat diperoleh di toko grosir makanan dan pasar tradisional. Dalam penentuan pemasokan bahan baku industri kecil ini lebih mengutamakan kualitas yang dimiliki oleh supplier bahan baku tersebut. Setelah itu, dilakukan negoisasi antar pemasok dan produsen keripik industri kecil melakukan persetujuan dalam pembelian bahan baku tersebut. Kemudian dilakukan pengecekan jenis bahan baku dan legalitas bahan yang dibeli tersebut sehingga tidak terjadi kesalahpahaman dalam pembelian bahan baku.

\section{SIMPULAN}

1. Strategi bersaing pada usaha mikro kecil keripik kemasan kota Bandung, Jawa Barat yang dilakukan agar dapat terus bertahan dalam menjalankan usahanya adalah:

a. Dilakukan pengenalan produk keripik dengan cara promosi lewat tetangga, komunitas, menitipkan di toko keripik terdekat dan internet - digital marketing. 
b. Agar tetap bersaing dengan produsen lain, produsen memilih peningkatan kualitas karena mereka tidak ingin mengecewakan konsumen.

c. Dari segi Tenaga Kerja, terlalu sedikit tenaga kerja yang digunakan oleh produsen sehingga dalam memproduksi keripik kurang efektif. Seharusnya tenaga kerja yang digunakan perlu ditingkatkan apabila dalam memproduksi keripik kurang cepat.

2. Strategi bertahan pada usaha mikro kecil keripik kemasan kota Bandung, Jawa Barat yang dilakukan agar dapat terus bertahan dalam menjalankan usahanya adalah:

a. Faktor penting dalam mengembangkan usaha industri keripik adalah lokasi, modal dan usaha.

b. Agar dapat melakukan pengembangan usaha produsen memilih membuka usaha keripik ditempat lain.

3. Lima Persaingan dari Porter pada usaha mikro kecil keripik kemasan kota Bandung, Jawa Barat yang dilakukan adalah:

a. Persaingan Antara Perusahaan Para produsen keripik memilih strategi bersaing terkait dengan harga jual produk yang diberikan pada konsumen.

b. Ancaman dari pendatang baru (potential entrants) Adanya sertifikasi dalam produk makanan agar diakui para konsumen bahwa produk yang dijual halal dan layak dimakan. Sehingga industri kecil ini bisa bersaing dengan usaha lainnya.

c. Ancaman produk pengganti Dalam membuka usaha keripik ini para produsen belum menemukan produk pengganti yang potensial terhadap produk keripik. Sehingga produsen harus terus melakukan inovasi yang baru agar dapat mengantisipasi jika ada ancaman produk pengganti.

d. Daya Tawar Pembeli Para produsen keripik dalam proses tawar menawar tentunya pembeli konsumen akan meminta penurunan harga dari harga yang telah ditetapkan oleh produsen. Oleh karena itu, para produsen menaikkan harga produknya terlebih dahulu, sehingga pada saat terjadi proses transaksi, penjual akan tetap mendapatkan keuntungan.

e. Daya Tawar Pemasok Dalam penentuan pemasokan bahan baku industri kecil ini lebih mengutamakan kualitas yang dimiliki oleh supplier bahan 
baku tersebut. Setelah itu, dilakukan negoisasi antar pemasok dan produsen keripik industri kecil melakukan persetujuan dalam pembelian bahan baku tersebut. Kemudian dilakukan pengecekan jenis bahan baku dan legalitas bahan yang dibeli tersebut sehingga tidak terjadi kesalahpahaman dalam pembelian bahan baku.

\section{DAFTAR PUSTAKA}

Kuncoro, M., (2005) Strategi Bagaimana Meraih Keunggulan Kompetitif, Penerbit Erlangga, Jakarta.

Kuncoro, M., (2009), Metode Riset Untuk Bisnis dan Ekonomi: Bagaimana Meneliti dan Menulis Tesis, Cetakan Pertama, Edisi ketiga, Penerbit Erlangga, Jakarta.

Porter, M., (1992), Keunggulan Bersaing Menciptakan dan Mempertahankan Kinerja Unggul, Cetakan Pertama, Erlangga, Jakarta.

Solihin, I., (2012), Manajemen Strategik, Cetakan Pertama, Erlangga, Jakarta. Thee Kian Wie., (1994) Industrialisasi di Indonesia Beberapa Kajian, Cetakan Pertama, Penerbit LP3ES, Jakarta.

Usmara, A., (2003), Implementasi Manajemen Stratejik: Kebijakan dan Proses, Cetakan Pertama, Amara Books, Yogyakarta.

Elyawati. J., Sri Susilo, Y., (2001) "Analisis Tingkat Keberhasilan Usaha Industri Kecil", Jurnal Kinerja, Volume 5, Nomor 1, Juni 2001, hal. 31-42 Khavidhurrohmaningrum., (2013), "Strategi dan Perilaku Industri Pengolahan di Kota Semarang Tahun 2007-2011", Economics Development Anaylis Journal, EDAJ Volume 2, Nomor 3, Agustus 2013, hal. 220-233

Lela Hindasah., (2011), "Strategi Survival dan faktor-faktor Penentu Survival Industri Kecil (Studi Empiris Industri Gerabah, Kasongan, Bantul, Yogyakarta)", Laporan Penelitian, Program Seminar International dan Call for papers "Towards Excellent Small Business", Universitas Muhammadiyah Yogyakarta. Rahmana Arief, Iriani Yani, dan Oktarina Rienna, (2012)., "Strategi Pengembangan Usaha Kecil Menengah Sektor Industri Pengolahan", Jurnal Teknik Industri, Volume 13, Nomor 1, Februari 2012, hal. 14-21

Sri Susilo, Y., Sukmawati, Y., dan Wahyu Ariani, D., (2003), "Kemampuan Bertahan Industri Kecil Pada Masa Krisis Ekonomi”, Jurnal Ekonomi dan Bisnis, Volume 5, Nomor 2, Juni 2003, hal. 116-133

Sri Susilo, Y., (2005), "Strategi Survival Usaha Mikro-Kecil (Studi Empiris Pedagang Warung Angkringan di Kota", Jurnal Telaah Bisnis, Vol.6, No.2, Desember 2005, hal. 161-177

Sri Susilo, Y., (2009a), "Strategi Bertahan Industri Makanan Skala Kecil Pasca Kenaikan Harga Pangan dan Energi di Kota Yogyakarta", Jurnal Ekuitas Vol.14 No.2 Juni $2010: 225-244$ 
Sri Susilo, Y., (2009b), "Strategi survival Menghadapi Krisis Ekonomi Global: Kasus Industri Kecil-Menengah di Provinsi Daerah Istimewa Yogyakarta", Jurnal Studi Ekonomi, IV (2), hal. 177-190)

Sutarta, Edi., 2005 "Dampak Perubahan Lingkungan Bisnis Terhadap Kegiatan Usaha Industri Kecil: Studi kasus pada beberapa Industri Kecil D.I.Yogyakarta”. Telaah Bisnis, Vol. 6 No. 2, Desember 2005

Sriyana Jaka., (2010), "Strategi Pengembangan Usaha Kecil dan Menengah (UKM) : Studi kasus di Kabupaten Bantul", Jurnal Simposium Nasional 2010: Menuju Purworejo Dinamis dan Kreatif, hal. 79-103

Badan Pusat Statistik, Tabel Perkembangan UMKM pada periode 1997-2012, diakses dari http://www.bps.go.od/tab_sub /view.php?kat= 2\&tabel= 1\&daftar =1\&id subyek=13\&notab=45 pada tanggal 6 Maret 2015. Definisi Strategi, diakses dari http://id.wikipedia.org/wiki/Strategi Tanggal 27 April 2015.

Usaha modal kecil: Kendala Usaha Kecil dan Menengah dan Solusi Cara Mengatasinya, 2012, diakses dari http://usahamodalkecil31.blogspot.com /2012/ 08/kendalausahakecil-menengah-dan-solusi.html pada tanggal 6 Maret 2015. Pengertian Industri menurut UU diakses dari http://geografi-geografi. blogspot.com /2010/11/pengertian-industri-menurut-uu-no.html pada tanggal 27 April 2015. 